\title{
Platform Halal Lifestyle dengan Aplikasi Konsep One Stop Solution
}

\author{
Ativa Hesti A, Risky Dwi Afriadi, Ceasar Pratama \& Ade Lestari \\ Program Studi Ekonomi Pertahanan, Fakultas Manajemen Pertahanan, \\ Universitas Pertahanan Bogor \\ Email: ativahestiagustina@gmail.com
}

\begin{abstract}
This research focuses on halal lifestyle as a market segment of Indonesian society. In Indonesia which has the largest majority of Muslim population, so the need for halal lifestyle needs for millennials, is faced with the situation of potential halal lifestyle developments that has not been optimally well and demanded by the presence of increasingly advanced technology. This study analyzes the SWOT approach to get answers about the importance of halal lifestyle in Indonesian society. The results of the study introduce and create opportunities and a large market share for Indonesia by using communication technology, especially the internet, which can provide a one stop solution in the form of halal lifestyle applications so as to maintain maqashid syariah.
\end{abstract}

Keywords: Halal Lifestyle, Halal Tourism, Application.

\begin{abstract}
ABSTRAK
Penelitian ini berfokus pada halal lifestyle sebagai segmen pasar masyarakat Indonesia. Indonesia memiliki mayoritas penduduk Muslim terbesar sehingga perlu adanya kebutuhan halal lifestyle bagi milenial, dihadapkan pada situasi potensi perkembangan halal lifestyle yang belum optimal dengan baik serta dituntut oleh hadirnya teknologi yang semakin maju. Penelitian ini menganalisa dengan pendekatan SWOT untuk mendapatkan jawaban tentang pentingnya halal lifestyle di masyarakat Indoensia. Hasil penelitian
\end{abstract}


memperkenalkan dan menciptakan peluang serta pangsa pasar yang besar bagi Indonesia dengan menggunkan teknologi komunikasi khususnya internet, yang dapat memberikan one stop solution berupa aplikasi halal lifestyle sehingga menjaga maqashid syariah.

Kata Kunci: Halal Lifestyle, Pariwisata Halal, Aplikasi.

1. Pendahuluan

Agama Islam dianut oleh lebih dari 1,6 milyar jiwa atau 20\% dari total penduduk dunia yang mencapai 7 milyar dan pasar konsumen muslim dunia mencapai nilai 2,7 Trilliun USD (Sapta, 2015). Indonesia merupakan negara terbesar ke-4 di dunia pada kategori jumlah penduduk serta mayoritas penduduk muslim di dunia. sehingga Indonesia merupakan pasar yang sangat potensial bagi berbagai produsen barang dan jasa. Meskipun masing-masing konsumen muslim memiliki kadar kepatuhan terhadap syariah yang berbeda-beda dan tergantung tingkat religiusitas mereka, secara umum konsumen muslim memiliki sikap positif terhadap produk-produk yang menggunakan pendekatan halal (Salehudin \& Mukhlis, 2012). Hal ini dapat memberi peluang untuk menciptakan halal lifestyle. Halal lifestyle terdiri dari makanan halal, pharmaceutical, cosmetics, halal travel, islamic financial, dan halal media. Halal lifestyle merupakan salah satu segmen pasar yang cukup baik untuk meningkatkan ekonomi. Kebutuhan akan halal lifestyle yang terlihat dari pengeluaran muslim di Indonesia tergambar sebagai berikut:

Tabel 1.1

Pengeluaran Masyarakat Muslim di Indonesia dan Dunia Pada Sektor Halal Life Style

\begin{tabular}{|c|c|c|c|}
\hline $\begin{array}{l}\text { Sector Halal } \\
\text { Life style }\end{array}$ & $\begin{array}{c}\text { Indonesia's } \\
\text { Moslem }\end{array}$ & $\begin{array}{l}\text { Global } \\
\text { Moslem }\end{array}$ & $\begin{array}{c}\text { Market } \\
\text { Share (\%) }\end{array}$ \\
\hline Food & US Dollar 190,4 Billion & $\begin{array}{l}\text { US Dollar 1,292 } \\
\text { Billion }\end{array}$ & 14,7 \\
\hline Finance & US Dollar 36 Billion & $\begin{array}{l}\text { US Dollar 1,214 } \\
\text { Billion }\end{array}$ & 3 \\
\hline $\begin{array}{l}\text { Travel (Excl. } \\
\text { Hajj \& Umrah) }\end{array}$ & US Dollar 7,5 Billion & $\begin{array}{l}\text { US Dollar } 140 \\
\text { Billion }\end{array}$ & 0,6 \\
\hline Fashion & US Dollar 18,8 Billion & $\begin{array}{l}\text { US Dollar } 266 \\
\text { Billion }\end{array}$ & 7 \\
\hline $\begin{array}{l}\text { Media \& } \\
\text { Recreation }\end{array}$ & US Dollar 9,37 Billion & $\begin{array}{l}\text { US Dollar } 185 \\
\text { Billion }\end{array}$ & 5 \\
\hline Pharmaceuticals & US Dollar 4,88 Billion & $\begin{array}{l}\text { US Dollar } 72 \\
\text { Billion }\end{array}$ & 6,7 \\
\hline
\end{tabular}




\begin{tabular}{llll}
\hline Cosmetics & US Dollar 3,44 Billion & $\begin{array}{l}\text { US Dollar 46 } \\
\text { Billion }\end{array}$ & 7,4 \\
\hline
\end{tabular}

Sumber: Halal Life style Di Indonesia (2015)

Indonesia memiliki potensi pengembangan potensi halal lifestyle namun belum teroptimalkan dengan baik. Data dibawah menunjukan Indonesia belum mampu memberikan sumbangan yang signifikan untuk halal lifestyle. Indonesia masih berada urutan 10 diantara 15 negara-negara lainnya. Peringkat ini diukur dengan Global Islamic Economy Indicator (GIEI) yang menunjukkan kondisi terkini mengenai pembangunan ekosistem ekonomi Islam. GIEI diukur melalui indikator-indikator makanan halal, jasa keuangan Islam, wisata halal, fashion halal, media halal, kosmetik dan farmasi halal.

Tabel 1.2

Global Islamic Economy Indicator beberapa negara

\begin{tabular}{|c|c|c|c|c|c|c|c|}
\hline $\begin{array}{l}\text { Top15 } \\
\text { countries }\end{array}$ & $\begin{array}{c}\text { GIE } \\
\text { indicator } \\
\text { score }\end{array}$ & $\begin{array}{l}\text { Halal } \\
\text { Food }\end{array}$ & $\begin{array}{c}\text { Halal } \\
\text { Travel }\end{array}$ & $\begin{array}{l}\text { Islamic } \\
\text { Finance }\end{array}$ & $\begin{array}{l}\text { Modest } \\
\text { Fashion }\end{array}$ & $\begin{array}{c}\text { Halal } \\
\text { Media and } \\
\text { Recreation }\end{array}$ & $\begin{array}{c}\text { Halal } \\
\text { Cosmetics }\end{array}$ \\
\hline Malaysia & 121 & 55 & 70 & 139 & 25 & 38 & 61 \\
\hline UEA & 86 & 92 & 81 & 92 & 67 & 137 & 78 \\
\hline Bahrain & 66 & 90 & 30 & 90 & 26 & 68 & 36 \\
\hline Saudi & 63 & 83 & 35 & 83 & 17 & 33 & 48 \\
\hline \multicolumn{8}{|l|}{ Arabia } \\
\hline Oman & 48 & 51 & 36 & 51 & 16 & 40 & 40 \\
\hline Pakistan & 45 & 47 & 11 & 47 & 19 & 8 & 52 \\
\hline Kuwait & 44 & 51 & 29 & 51 & 13 & 45 & 29 \\
\hline Qatar & 43 & 47 & 35 & 47 & 15 & 46 & 32 \\
\hline Jordan & 37 & 36 & 39 & 36 & 19 & 31 & 49 \\
\hline Indonesia & 36 & 38 & 35 & 38 & 21 & 9 & 41 \\
\hline Singapore & 32 & 22 & 44 & 22 & 26 & 75 & 56 \\
\hline Brunei & 32 & 27 & 22 & 27 & 12 & 30 & 39 \\
\hline Sudan & 28 & 30 & 23 & 30 & 5 & 17 & 23 \\
\hline Iran & 28 & 30 & 36 & 30 & 10 & 20 & 27 \\
\hline Bangladesh & 26 & 31 & 10 & 31 & 25 & 3 & 25 \\
\hline
\end{tabular}

Sumber: State of the Global Economic Report (2018)

Pada tahun 2020 hingga 2030 Indonesia akan mengalami bonus demografi. Di periode ini kemungkinan jumlah penduduk berusia muda akan sangat banyak, bahkan menurut beberapa lembaga dapat menembus 40 persen dari total penduduk Indonesia (Faisal, 2017). Fakta tersebut menyebabkan dewasa ini Indonesia dihadapkan pada keberadaan generasi milenial. Milenial adalah generasi pertama yang menyandang digital native, yang berarti bahwa penggunaan teknologi merupakan hal terpenting pada era ini, seperti perilaku generasi melenial di Indonesia saat ini yang sangat candu pada internet. Hal yang bisa dilakukan cukup beragam dan terkait apa saja yang dapat memberi peluang 
penerapan halal lifestyle platform, seperti liburan kapan saja, dimana saja, kerja cepat dan kerja cerdas. Berikut ini merupakan beberapa data jumlah banyaknya milenial Indonesia dan negara lain yang menjadi potensi bagi penerapan halal lifestyle. Dapat dilihat berdasarkan data di bawah, Indonesia menempati peringkat satu dalam hal jumlah interaksi millenial di bidang halal lifestyle.

Tabel 1.3

Volume dari interaksi millenial per negara dan sektor

\begin{tabular}{lccccccc}
\hline Countries & $\begin{array}{c}\text { Islamic } \\
\text { Finance }\end{array}$ & $\begin{array}{c}\text { Halal } \\
\text { Food }\end{array}$ & $\begin{array}{c}\text { Modest } \\
\text { Fashion }\end{array}$ & $\begin{array}{c}\text { Halal } \\
\text { Travel }\end{array}$ & $\begin{array}{c}\text { Halal } \\
\text { Media }\end{array}$ & $\begin{array}{c}\text { Halal } \\
\text { Cosmetics }\end{array}$ & Total \\
\hline Indonesia & 37.500 & 4.200 & 68.500 & 4.600 & 4.200 & 7.800 & 128.800 \\
\hline Malaysia & 60.600 & 7.400 & 5.300 & 1900 & 1.400 & 8.100 & 84.700 \\
\hline Pakistan & 4.000 & 1.200 & 1.500 & 500 & 48.500 & 200 & 55.900 \\
\hline USA & 2.500 & 6.800 & 1.100 & 1500 & 2.200 & 500 & 14.600 \\
\hline Filipina & 400 & 7.700 & 1.200 & 100 & 200 & 4.300 & 13.900 \\
\hline India & 1.800 & 2.500 & 500 & 300 & 5.200 & - & 10.300 \\
\hline $\begin{array}{l}\text { Saudi } \\
\text { Arabia }\end{array}$ & 900 & 600 & 900 & 100 & 5.300 & - & 7.800 \\
\hline UK & 600 & 2.700 & 400 & 300 & 1.000 & 100 & 5.100 \\
\hline Turkey & - & - & - & - & 4.900 & - & 4.900 \\
\hline UAE & 300 & 300 & 200 & - & 3.000 & - & 3.800 \\
\hline
\end{tabular}

Sumber: State of the Global Economic Report (2018)

Pada dasarnya konsep dari halal lifestyle sederhana, karena suatu yang halal sudah pasti baik, bersih, dan sehat tentunya. Bila kita mengkonsumsi yang halal maka akan mendapat sebuah kebaikan dan terhindar dari keburukan. Oleh sebab itu negara-negara yang bukan mayoritas berpenduduk muslim juga ikut berpartisipasi dalam Maka tidak heran bahwa negara non muslim juga ikut berpartisipasi dalam halal lifestyle ini. Saat ini telah banyak sektor yang mendukung penerapkan gaya hidup halal. Halal lifestyle dapat memenuhi kebutuhan sehari-hari masyarakat, baik dalam dunia jasa keuangan, wisata, obatobatan yang berbahan dasar halal, makanan-minuman, pakaian sehari-hari, komestik bagi penampilan, serta pola hidup lainnya yang berbasis prinsip syariah yakni halal.

Teknologi informasi di era globalisasi saat ini memiliki dampak signifikan dan positif bagi sejumlah pelaku usaha untuk menghasilkan dan memasarkan produk barang dan jasa halal lifestyle untuk skala dan jangkauan pasar yang lebih luas. Kehadiran teknologi informasi memunculkan banyak peluang usaha untuk memperkenalkan halal lifestyle. Faktanya, internet sangat berperan terhadap perubahan yang signifikan tersebut terutama pada proses transformasi bisnis ke arah digitalisasi. Kondisi ini memungkinkan adanya penurunan biaya interaksi, transformasi, dan juga meningkatkan jumlah pendapatan. Kegiatan interaksi menjadi lebih mudah karena tidak perlu hadir secara fisik atau secara langsung. 
Selain itu akan memunculkan lebih banyak alternatif pilihan pencapaian dan lebih murah serta peluang juga menjadi lebih luas. Platform elektronik dapat digunakan untuk memenuhi kebutuhan yang berbasis syariah sekaligus dapat mencapai tujuan dari maqasid al shariah.

Penerapan halal lifestyle di Indonesia masih tergolong rendah dan membutuhkan sosialisasi lebih untuk memperkenalkan halal lifestyle. Sosialisasi dapat dilakukan dengan cara memanfaatkan kecanggihan teknologi berbasis internet. Hal ini terbukti dari laporan Global Islamic Economic, Indonesia masih berada di urutan 10 (sepuluh) dan jauh di bawah Malaysia yang memiliki penduduk muslim lebih sedikit. Pangsa pasar Indonesia yang besar membuat peluang halal lifestyle terbuka lebar. Beberapa peluang yang sudah ada di Indonesia ialah melalui makanan nusantara yang beraneka ragam yang menggunakan bahan-bahan halal, aneka komestik yang telah mengantongi sertifikat produk halal dan sertifikat BPOM sehingga dapat dikonsumsi dengan baik, dan dunia keuangan syari'ah yang menggunakan dual banking system yang artinya penduduk Indonesia dapat memilih untuk menggunakan bank konvensional maupun syariah. Meskipun memiliki peluang yang besar akan tetapi masih ada yang perlu diperhatikan mengenai ancaman yang dapat timbul, seperti dalam penggunaan teknologi yang buruk dan merusak produktifitas generasi melenium.

\section{Landasan Teori}

\subsection{Halal dan Haram}

Bank Perkreditan Rakyat (BPR) menurut Undang-Undang (UU) Perbankan No. 7 tahun 1992, adalah lembaga keuangan bank yang menerima simpanan hanya dalam bentuk deposito berjangka tabungan dan/ atau bentuk lainnya yang dipersamakan dengan itu dan menyalurkan dana sebagai usaha BPR. Sedangkan pada UU Perbankan No. 10 tahun 1998, disebutkan bahwa BPR adalah lembaga keuangan bank yang melaksanakan kegiatan usahanya secara konvensional atau berdasarkan prinsip syariah (Sudarsono, 2007: 83).

Pelaksanaan BPR yang melakukan kegiatan usaha berdasarkan prinsip syariah selanjutnya diatur menurut Surat Keputusan Direktur Bank Indonesia No. 32/36/KEP/DIR/1999 tanggal 12 Mei 1999 tentang Bank Pengkreditan Rakyat Syariah. Dalam hal ini, secara teknis BPR syariah bisa diartikan sebagai lembaga keuangan sebagaimana BPR konvensional, yang operasinya menggunakan prinsip-prinsip syariah (Sudarsono, 2007: 83).

Halal dan haram telah jelas disebutkan oleh Allah SWT namun pemahaman mengenai kaidah halal masih belum sempurna bahkan di kalangan umat islam yang menjadi pelaku usaha bisnis halal. Umumnya masyarakat memahami perkara halal-haram hanya pada lingkup makanan dan minuman semata. Pada kenyataannya ada hal lain dalam perkara halal-haram yang harus diperhatikan lebih lanjut. Halal dan haram dalam Islam akan mencakup semua perihal dalam kehidupan. Menurut Al-Qardhawi, satu-satunya kriteria untuk mendefinisikan halal dan haram ialah perintah al-Quran yang diturunkan oleh Allah saja (Al Qardhawi, 2001). 
Asia tenggara dan Asia Timur tengah merupakan dua pasar yang memiliki kekuatan yang baik bagi penerapan produk halal. Asia tenggara populasinya lebih dari 250 juta jiwa yang didominasi oleh Indonesia yang penduduknya juga mayoritas muslim. Dampak penerapan halal dan haram pada pembelian konsumsi halal lifestyle menjadi potensi yang dimiliki sehingga dapat mengikuti ajaran agama Islam (Ismail \& Phoon, 2009).

Lifestyle dapat dipahami sebagai pola dalam penggunaan, pemahaman, atau penghargaan artefak-artefak budaya material untuk menegosiasikan permainan kriteria status dalam kontek sosial (Chaney, 1996). Lifestyle ciri sebuah dunia modern karena dunia modern gaya hidup akan membantu mendefinisikan sikap, nilai-nilai, dan menunjukan kekayaan serta posisi sosial. Maka gaya hidup dianggap merupakan proyek yang penting daripada waktu luang (Rinawati, 2007). Lifestyle juga dapat diartikan sebagai simbol dari artefak-artefak tersebut dengan maksud yang terlihat mempresentasikan tentang identitas keberadaan lifestyle. Dengan demikian gaya hidup merupakan cara-cara terpola menginventasikan aspek-aspek tertentu kehidupan. Gaya hidup mencirikan dunia modern karena dunia gaya hidup modern akan membantu mendefinisikan sikap, nilai, dan menunjukan kekayaan dan posisi sosial. Jadi lifestyle dianggap sebagai proyek penting daripada waktu luang.

Lifestyle halal meliputi beberapa hal yang mampu mendifinisikan suatu pola kehidupan yang islami, yaitu fashion, makanan-minuman, wisata halal, dan penggunaan kosmetik dan obat-obatan. Lifestyle dalam hal fashion akan mewakili identitas dari penggunanya, sehingga busana Islami juga akan menunjukkan identitas diri pemakainya sebagai seorang muslim. Busana Islami telah diatur dalam pedoman al-Quran surat (QS. Al-A'raf[7]: 26). Halal lifestyle memberikan pengaruh pada fashion pakaian yang saat ini digunakan, sehingga perlu ditekankan bahwa pakaian harus sesuai dengan ketentuan dan aturan Allah SWT.

Selain itu, makanan dan minuman juga telah diatur Islam. Kewajiban umat ialah mengkonsumsi sesuatu yang halal dan juga bersifat toyyiban atau higienis (QS. Baqarah[2]: 168).

Dalam hal pariwisata, Indonesia memiliki strategi yang baik dalam wisata halal. Orientasi yang dibangun ialah pengembangan ekosistem pariwisata untuk meningkatkan daya saing melalui kepedulian terhadap lingkungan, komunitas, komunitas, pemerintah, pelaku bisnis terkait pariwisata dan semua pihak terkait untuk bersama-sama menciptakan citra yang baik (Nugroho, 2017). Islam di Indonesia memiliki kesan yang baik dan dikenal secara internasional dengan Islam yang damai. Kesan ini harus menjadi pintu gerbang menuju pariwisata halal di Indonesia untuk mengembangkan pariwisata halal yang berorientasi ekosistem. Meskipun Indonesia tidak menempati peringkat pertama dalam kunjungan wisata halal, ini dapat menjadi potensi besar bagi Indonesia karena memiliki banyak tempat wisata yang dapat menjadi kunjungan ke komunitas dunia. 
Di Indonesia, ketersediaan komestik dan obat-obatan untuk memenuhi kebutuhan hidup manusia dilakukan dengan berbagai prosedur sehingga mampu dipasarkan. Komestik dan obat-obatan yang telah melewati BPOM maka layak untuk diedarkan dengan baik, akan tetapi untuk memberikan rasa nyaman kepada konten, label halal diperlukan oleh MUI untuk menjamin produk halal dan aman yang digunakan oleh umat Islam di Indonesia.

\section{Metode Penelitian}

Penelitian ini menggunakan pendekatan kualitatif yang menghasilkan penemuan-penemuan yang tidak dapat dicapai dengan menggunakan produserproduser statistik atau metode lain dari kuantifikasi (pengukuran). Penelitian kualitatif bertujuan memahami realitas sosial, yaitu melihat suatu fenomena dari apa adanya, bukan fenomena yang seharusnya. Kualitatif disebut sebagai paradigma interaktif dan konstruktif, yang memandang realitas sosial sebagai sesuatu yang holistik/ utuh, kompleks, dinamis, penuh makna, dan hubungan gejala bersifat interaktif (Sugiyono, 2011). Penelitian kualitatif dengan Pendekatan SWOT (Stregth, Weaknes, Opportunity dan Threats). Pendekatan SWOT adalah pendekatan yang menekankan untuk mengevaluasi proyek dengan memahami situasi dan informasi yang ada (Freddy, 2006), serta berorientasi pada factor internal dan ekternal bertujuan menemukan solusi yang tepat dengan mengetahui kekuatan, kelemahan, peluang dan ancaman. Apabila telah dilakukan SWOT akan terbentuk kekuatan untuk memberi gambaran solusi terbaik. Pendekatan SWOT memberikan alternative strategi yang dapat digunakan untuk mengembangkan produk seperti: Efisiensi biaya, strategi diversifikasi konsentrasi/integral horizontal, pengembangan produk, memperkuat lembaga research \& development dan penerapan teknologi baru (Freddy, 2006).

\section{Pembahasan}

Latar belakang di awal menyatakan bahwa populasi masyarakat di Indonesia didominasi oleh generasi milenium dan penggunaan internet yang cukup tinggi serta membuka peluang untuk menciptakan segmen pasar yang besar untuk kebutuhan gaya hidup halal. Hal ini diperkuat oleh analisis SWOT yang menunjukkan adanya manfaat memberikan prioritas penting pada gaya hidup halal dalam mencapai maqashid syariah. Terciptanya prioritas dalam pendekatan SWOT dapat dijadikan acuan dasar untuk memperkokoh terbentuknya halal lifestyle berbasis internet. Dalam pembentukan analisis SWOT diperlukan nilainilai prioritas yang menjadi poin penting terbentuknya kekuatan. 
Tabel 1.4.

Analisi SWOT

\begin{tabular}{|c|c|c|}
\hline Faktor internal & $\begin{array}{l}\text { Kekuatan: } \\
\text {-Jumlah penduduk besar } \\
\text { segmen remaja dan anak- } \\
\text { anak } \\
\text {-Pangsa pasar halal } \\
\text { lifestyle tinggi } \\
\text { - penggunaan Internet } \\
\text { yang tinggi }\end{array}$ & $\begin{array}{l}\text { Kelemahan : } \\
\text {-Sumber daya tidak dieksplor } \\
\text { dengan baik } \\
\text {-tidak menggunakan internet } \\
\text { dengan baik } \\
\text {-belum banyak penggunaan } \\
\text { halal lifestyle }\end{array}$ \\
\hline $\begin{array}{l}\text { Peluang : } \\
\text {-Jumlah penduduk } \\
\text { muslim terbesar di Asia } \\
\text { tenggara dan dunia } \\
\text {-generasi melenium } \\
\text { cenderung } \\
\text { menggunakan Internet }\end{array}$ & $\begin{array}{l}\text { SO : } \\
\text { Menciptakan segmen } \\
\text { pasar gaya hidup halal } \\
\text { baru untuk kaum muda } \\
\text { melalui internet dan } \\
\text { gadget }\end{array}$ & \begin{tabular}{l}
\multicolumn{1}{c}{ OW : } \\
Menciptakan pangsa pasar \\
pendidikan dalam generasi \\
melenium melalui \\
penggunaan internet sebagai \\
sarana promosi
\end{tabular} \\
\hline $\begin{array}{l}\text { Ancaman : } \\
\text {-Ancaman keamanan } \\
\text { negara } \\
\text {-penyalahgunaan } \\
\text { penggunaan internet } \\
\text {-remaja tidak produktif }\end{array}$ & \begin{tabular}{l}
\multicolumn{1}{c}{ TS : } \\
Mengundang halal \\
lifestyle kepada generasi \\
muda dengan \\
memanfaatkan \\
penggunaan internet
\end{tabular} & \begin{tabular}{l}
\multicolumn{1}{c}{ TW : } \\
Menciptakan Pendidikan \\
internet untuk pemahaman \\
lifestyle berbasis halal \\
(syariah)
\end{tabular} \\
\hline
\end{tabular}

Dari analisis SWOT di atas telah menunjukkan pentingnya platform gaya hidup halal dengan pendekatan kekuatan, selanjutnya mengenai kelemahan dalam faktor internal yang memengaruhi keberadaan halal lifestyle seperti jumlah penduduk yang cukup besar dan penggunaan internet tinggi sementara: peluang dan ancaman diperlakukan dalam faktor eksternal yang salah satunya adanya penyalahgunaan penggunaan internet, remaja yang tidak produktif, dan bahkan dapat mengancam kedaulatan negara. Menciptakan segmen pasar gaya hidup halal baru untuk kaum muda melalui internet dan gadget sangat penting untuk memberikan manfaat bagi para pencapaian hukum Islam, selain memenuhi prinsip syariah kaum muda menggunakan internet juga menjadi bagian kebutuhan dalam era globalisasi yang saat ini mencapai generasi melenium. Terciptanya segmen pasar halal lifestyle karena adanya peluang Jumlah penduduk Muslim terbesar di Asia tenggara dan dunia dan didukung usia produktif karena adanya kebutuhan halal lifestyle. 
Pendekatan SWOT memberikan ilustrasi bahwa populasi Muslim yang tinggi yang dilengkapi dengan kemampuan penggunaan internet yang tinggi dapat menimbulkan ancaman dalam bentuk penyalahgunaan layanan internet yang tidak patut. Dampak negatif dari penggunaan internet dapat diminimalisir dengan mengundang halal lifestyle kepada generasi muda dengan memanfaatkan internet dengan baik sehingga menciptakan pendidikan internet yang berbasis halal lifestyle. Pengelolaan penggunaan layanan internet dengan baik dapat memiliki pengaruh besar dan memberikan peluang usaha yang menjanjikan bagi terciptanya segmen pasar yang besar terutama lifestyle halal. Sehingga perkuatan pembentukan aplikasi halal lifestyle menjadi penting untuk diimplementasikan.

\subsection{Halal Lifestyle Platform Implementation (One Stop Solution Concept)}

Pemasaran dapat didefinisikan sebagai proses sosial ketika individu atau kelompok mendapatkan apa yang mereka butuhkan dan inginkan, melalui penciptaan, penyediaan dan pertukaran barang dan jasa yang memiliki nilai tertentu dengan individu atau kelompok lain secara bebas, maka pemasaran halal dapat didefinisikan sebagai proses sosial di mana individu atau kelompok dapat memperoleh apa yang mereka butuhkan dan inginkan melalui penciptaan, penyediaan dan pertukaran barang dan jasa yang memiliki nilai tertentu dengan individu atau kelompok lain sesuai dengan aturan dan pedoman yang ditetapkan oleh kepatuhan syariah islam. Islam memberikan pedoman kepada pemasar untuk melakukan upaya pemasaran yang mempromosikan nilai-nilai moral, konsep Pemasaran Halal secara umum memiliki kesamaan dengan konsep pemasaran yang ada, yaitu dengan memperhatikan 4P (produk, harga, promosi, dan tempat), tetapi ada beberapa hal yang berbeda, misalnya aspek produk, aspek produk tidak boleh mengandung unsur atau bahan baku yang dilarang, maka dalam aspek penetapan harga, penetapan harga tidak mengandung unsur perjudian, gharar, riba, dan mengambil keuntungan yang wajar. Lebih jauh, dalam aspek promosi, aspek promosi tidak diizinkan menggunakan penipuan atau promosi berlebihan sehingga tampak menipu atau sumpah palsu, dan tidak diperbolehkan menggunakan daya tarik seks yang berlebihan, maka pada aspek tempat, aspek tempat adalah tidak diperbolehkan berjualan di tempat-tempat yang dilarang seperti masjid atau di waktu-waktu terlarang seperti waktu sholat.

Produk halal yang telah beredar di pasaran masih membutuhkan cara pemasaran yang unik dan berbeda sambil menjaga aspek pemasaran sesuai dengan prinsip syariah. Akan tetapi saat ini tidak ada platform bagi produk halal untuk mencakup berbagai e-commerce yang menjual produk halal. Hal ini menyebabkan kurangnya produk halal terintegrasi yang membuat konsumen ragu-ragu dalam memenuhi kebutuhan hidup mereka untuk produk dengan sertifikasi halal. Penggunaan produk halal menjadi sangat penting karena hal ini merupakan salah 
satu cara untuk menjaga maqashid syariah bagi umat Islam serta tuntutan perubahan-perubahan social yang terjadi pada era globalisasi. Dalam cara menggunakan produk halal dari aspek maqashid syariah adalah untuk melindungi agama dan jiwa. Dalam konteks melindungi agama, menggunakan produk bersertifikat halal serta menjalankan bisnis halal berarti menjalankan agama secara teratur menggunakan produk halal sesuai dengan aturan syariah. Padahal dalam konteks melindungi jiwa, menggunakan produk halal yang sudah bersertifikat dapat dipastikan bahwa produk tersebut aman dan tidak mengandung zat yang dilarang dan berbahaya bagi tubuh. Karena itu, produk halal adalah produk universal karena membawa kebaikan bagi siapa saja yang menggunakannya. Produk halal menjadi bagian dari kategori produk halal lifestyle termasuk pakaian, kebutuhan perumahan, mobil, kesehatan, perjalanan, kebutuhan sehari-hari, dan lain-lain. Kebutuhan akan produk halal umumnya adalah kebutuhan seluruh orang, tetapi dalam konteks produk halal di spesifikasi ini sangat dekat dengan milenium. Kita dapat melihat pembuktian ini tokoh masyarakat yang mulai berkampanye untuk gaya hidup halal, terutama di media sosial. Jadi metode pemasaran harus menggunakan metode yang akrab dengan generasi milenial yaitu penggunaan internet yang tinggi, salah satunya adalah dengan pemanfaatan media sosial dan gadget sehingga terbentuk aplikasi halal lifestyle.

Gambar 1.1.

Halal lifestyle dalam Platform

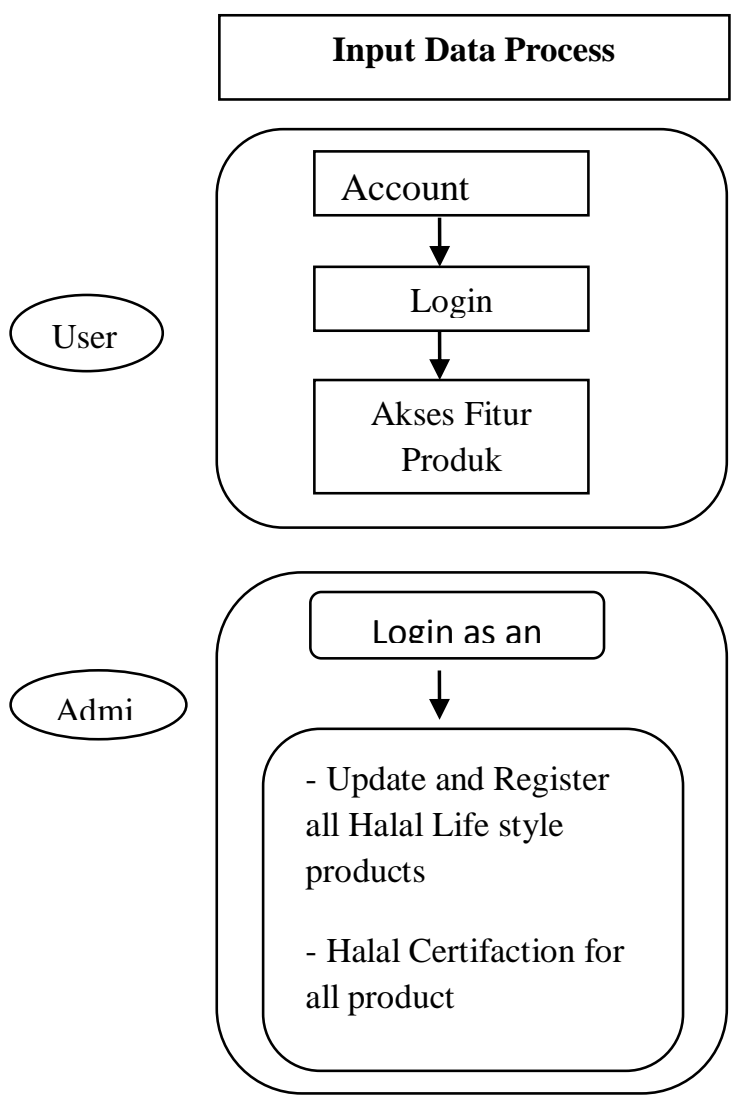

FALAH Jurnal Ekonomi Syariah
Halal Service Process

1. Halal Life style

- Clothes

- Pants

- $\quad$ Cosmetics \& Perfumes

- HIjab

2. House

- Landed House - Apartment

3. Car

- New

- Second

4. Hajj, Umra \& Travel

- Hotel

- Tourism

- Flight

5. Food

6 Health 
Era digital saat ini membutuhkan platform aplikasi mobile yang mampu memfasilitasi semua orang dan mudah digunakan dimanapun tempatnya, terutama generasi milenial yang mengakses berbagai kebutuhan produk halal untuk mencapai kemanfaatan dan kemaslahatan. Platform ini didasarkan pada aplikasi untuk ponsel yang dapat diakses dengan mudah dan biaya yang terjangkau. Untuk dapat menggunakan aplikasi ini tahapan yang dilakukan ialah pengguna harus mengunduh aplikasi ini, selanjutnya pengguna melakukan registrasi melalui email. Verifikasi dibutuhkan pada saat masuk ke laman email untuk mengaktifkan penggunaannya. Setelah tahapan tersebut telah dilakukan maka pengguna telah dapat mengakses seluruh pasar tempat produk halal. Tahap ini telah menjadi langkah umum yang dilakukan oleh berbagai aplikasi yang ada.

Gambar 1.2

Aplikasi Halal Ecosystem

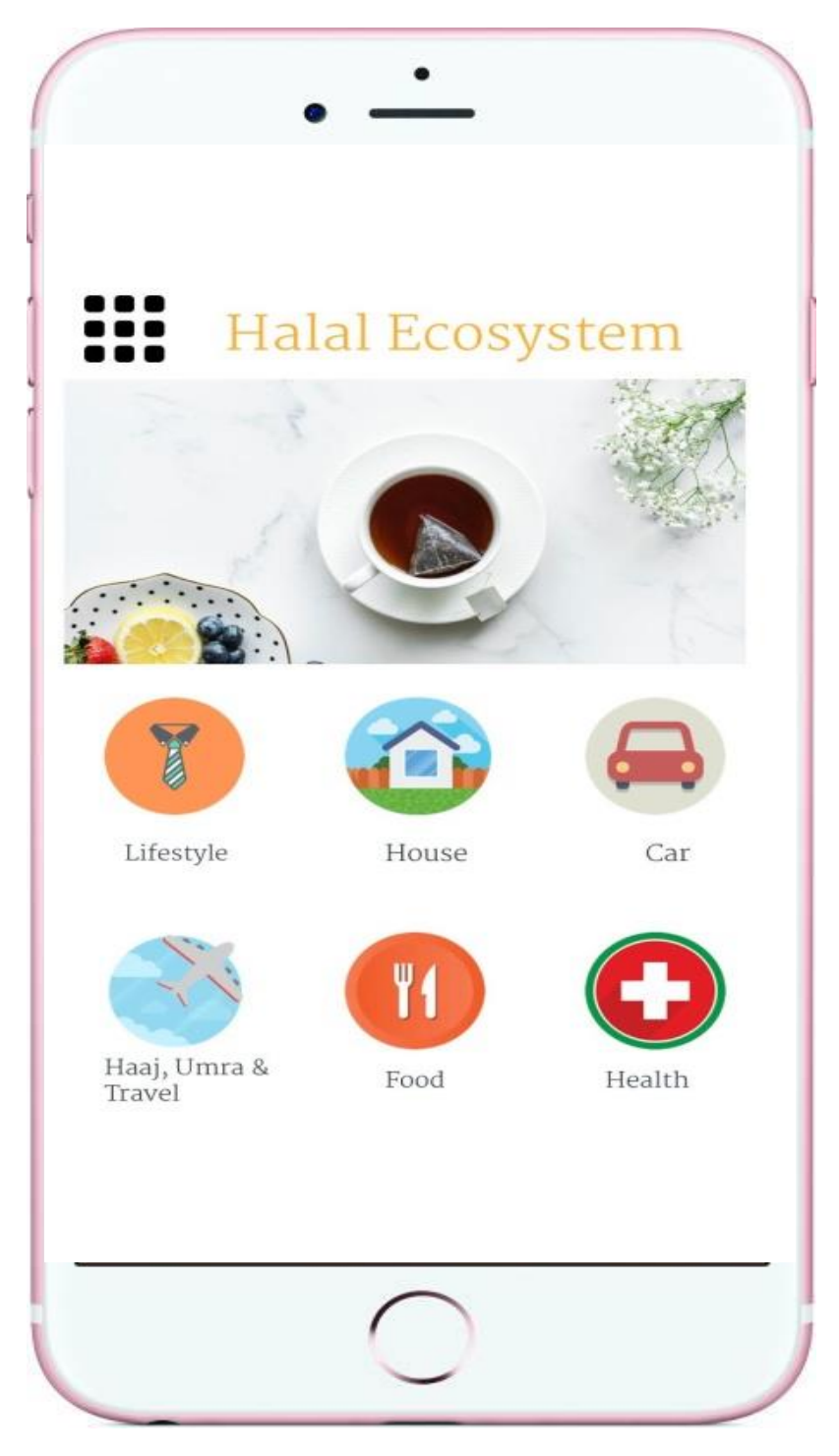

Vol. 4, No.1, Februari 2019 
Aplikasi pasar produk halal, seperti gambar di atas, menggunakan konsep one stop solution berdasarkan kategorisasi produk. Dengan aplikasi yang satu ini siapapun dapat mengakses kebutuhan berbagai produk bersertifikat halal. Aplikasi ini menggabungkan beberapa e-commerces yang menyediakan produk halal yang sering digunakan sebagai gaya hidup halal. Misalnya, jika Anda mengklik ikon gaya hidup halal, maka yang muncul ialah opsi e-commerce yang menyediakan produk-produk seperti pakaian, celana, kosmetik, dan berbagai kebutuhan seharihari. E-commerce yang ditampilkan dalam aplikasi ini adalah E-commerce yang secara khusus menyediakan produk bersertifikat halal, sehingga tidak ada keraguan bagi orang untuk menggunakan produk ini. Selain untuk kebutuhan sehari-hari, aplikasi ini juga menyediakan kebutuhan seperti rumah, mobil, haji, umrah, dan perjalanan, jika orang membutuhkan pembiayaan untuk kebutuhan tersebut, aplikasi ini akan dihubungkan dengan lembaga keuangan syariah, sehingga aplikasi ini tidak hanya terintegrasi dengan e-commerce, tetapi juga pihak lain yang mendukung konsep solusi satu atap seperti lembaga keuangan syariah seperti Bank dan Asuransi yang berbasis syariah.

\section{Kesimpulan}

Gaya hidup halal berkaitan erat dengan generasi milenial, kecenderungan dalam memanfaatkan teknologi, khususnya pengguna internet cukup tinggi. Ini akan menjadi tantangan dan peluang. Internet tidak akan menjadi tantangan jika disalahgunakan menjerumuskan ke hal-hal negatif, dan menjadi peluang ketika digunakan dengan benar. Paparan halal lifestyle dengan penggunaan internet adalah solusi penggunaan internet yang bijak. Gaya hidup halal terkait dengan bagian dari komunitas muslim dan itu harus ditegakkan untuk mencapai maqashid Islam. Gaya hidup halal perlu dikembangkan dalam suatu platform mengingat kebutuhan gaya hidup semakin penting. Platform gaya hidup halal adalah salah satu solusi terbaik untuk menyediakan semua gaya hidup halal yang harus dimiliki setiap Muslim dan memberi peluang ekonomi pelaku bisnis untuk segmen halal atau berprinsip syariah. Platform aplikasi ekosistem syariah memberikan kemudahan untuk menunjang halal lifestyle yang saat ini benar-benar dianggap penting karena adanya industry 4.0 segalanya dapat berorientasi pada internet of things. 


\section{Reference}

Alom and Haque, (2011). Marketing: An Islamic Perspective. World Journal of Social Sciences Vol 1 No 3

Al-Qaradawi, S. Y. (2001). The Lawful and the Prohibited in Islam (2nd ed.). Cairo: Al -FalahFoundation.

Alqudsi, Syed Ghazaly. (2013) Awareness and Demand for 100\% Halal Supply Chain meat products. Procedia Sosial and Behavioral Sciences 130

Al-syatibi, abu Ishak Ibrahim ibn musa bin muhaman (1997). Al-muwafaqat fi Ushul al-syari'ah jilid 2. Dar ibn Affan

Anderson, R.H (1976). Selecting \& Developing Media for Instruction. Wescosin: America Society for Traning and Development

Antara, Purnomo; Rosidah \& Faridah (2016) Bridging Islamic Financial Literacy and Halal Literacy: the way forward in halal ecosystem. Procedia Economics and finance

Boediman, eko Putra. (2017) Halal Life style in Marketing Communication of Tourism and Hospitality. Internasional Journal of Economic Research.

Departemen Agama RI. (2011). Al-qur'an dan Terjemahannya. Jakarta: Lentera Abadi.

Faisal, Muhammad. 2017. Generasi Phi, Memahami generasi milenial Indonesia. Jakarta:Republika

Ghofar, Shidiq (2009). Teori Maqashid Al-syari'ah dalam Hukum Islam. Jounal Sultan Agung Vol XLIV No 118

Ismail, K., \& Phoon, O.F. (2007). Consumer Intention in Purchasing Halal Food Products. Retrieved on December 282009.

Kearney, (2006) Habitat, environment and niche : what are we Modelling? Wiley online Library Oikos/Vol 115, issue 1

Kosasi, Sandy. (2015) Perancangan Sistem E-commrece untuk Produk Pembuatan Kue. CSRID Journal, vol 7

Mutakin, Ali (2017) Teori Maqashid Al syariah dan hubungan dengan metode Istinbath hukum. Jurnal Ilmu Hukum Kanun Vol 9 No 3

Nirwandar. Sapta (2015) Halal Life style in Indonesia. UNWTO Seminars

Nugroho, Lucky.(2017). Ekosistem Bisnis wisata halal dan peningkatan daya saing wisata Indonesia. Article from https://www.researchgate.net/publication/

Rangkuti, Freddy (2006) Analisis SWOT: Teknik Membedah Kasus Bisnis. Jakarta: PT Gramedia Pustaka Utama.

Rinawati, Rini.(2007). "Life style" Moslemah. MediaTor, Vol 8 No 1

Salehudin, Imam \& Basuki Muhamad. Pemasaran Halal: konsep, Implikasi dan Temuan Lapangan. Jakarta: Lembaga Penerbit Fakultas Ekonomi UI

Samori, Zakiah \& Noorsalawati Sabtu. (2014) Developing halal standard for Malaysian Hoel Industry: An exploratory Study. Procedia Sosial and Behavioral Sciences 121 pg 144-157 State of the Global Economic Report. 201

Sugiyono (2011). Metode Penelitian Kuantitatif, Kulaitatif dan R \& D, Bandung: Alfabeta, hlm. 8

http://econ3.upm.edu.my/epms/view.php?cat=journal\&jt=ll 